\title{
A Longitudinal Study of American and Canadian Convenience Store Marketing Strategies
}

\author{
Lise Heroux ${ }^{1}$ \\ School of Business and Economics, State University of New York-Plattsburgh, \\ Correspondence: Lise Heroux, School of Business and Economics, State University of New York-Plattsburgh, \\ 101 Broad Street, Plattsburgh, NY 12901 USA.
}

Received: May 27, 2020

doi:10.5539/ibr.v13n8p66
Accepted: July 8, $2020 \quad$ Online Published: July 21, 2020

URL: https://doi.org/10.5539/ibr.v13n8p66

\begin{abstract}
Convenience stores are part of the Canadian and American landscape. Consumers depend on them for fuel, coffee, tobacco, snacks, fast-food, bathrooms, and more. Convenience stores account for more than one third of the retail brick-and-mortar sales. Yet, there is a paucity of marketing research on this retail format. The present study examines the marketing strategies of convenience stores in 2008 and 2018, assessing the changes in strategy over a decade in the U.S. and Canada. The findings indicate that convenience stores in both regions have been able to offer products and services that will bring about repeat sales and increase their profitability. Convenience stores offer customers time saving while providing what they value most: fast service, expedient locations, quality customer service and an adapted marketing mix. Although there were more similarities than differences in marketing strategies in both regions, Quebec convenience stores were the most effective in implementing their marketing mix and adapting their strategy. Implications for convenience stores are discussed.
\end{abstract}

Keywords: convenience store, marketing strategy, Canada, US, longitudinal

\section{Introduction}

The National Association of Convenience Stores (National Association of Convenience Stores, 2020), defines a convenience store as "...a retail business with primary emphasis placed on providing the public a convenient location to quickly purchase from a wide array of consumable products (predominantly food or food and gasoline) and services." Three minutes 33 seconds. That is the average length of time that it takes consumers to leave their car, shop and purchase something in a convenience store, and return to their cars (The State Journal, 2011).

There are 152720 convenience stores in the United States - or one for about every 2100 people - and they account for more than one-third (35\%) the retail brick-and-mortar universe tracked by Nielsen in the United States (NACS, 2020). According to this source, an average convenience store selling fuel has around 1100 customers per day, or more than 400000 per year, and cumulatively, the U.S. convenience store industry alone serves nearly 165 million customers per day, and 58 billion customers every year. These retailers sell an estimated $80 \%$ of all the fuel purchased in the country.

There are over 26000 convenience stores throughout Canada, which collectively employ over 227000 and serve 10 million customers every day (3.65 billion customers per year) in communities across the country (Canadian Convenience Store Association, 2017). According to this source, this represents a contribution of more than $\$ 56$ billion per year to the Canadian economy and collecting over $\$ 21$ billion in taxes that support vital public services.

Convenience stores typically have the following characteristic: less than 5000 square feet in size, off-street parking and/or convenient pedestrian access, extended hours of operation (many open 24 hours 7 days a week), stocking at least 500 stock keeping units and have a product mix including beverages, snacks, tobacco and fuel/gasoline. C-stores, as industry insiders call them, can be categorized according to six formats (NACS, 2020):

- Kiosk: less than 800 sq. ft., mostly gas, tobacco, beverages and snacks;

- Mini convenience store: $800-1200$ sq. ft.; popular with oil companies, thin selection of grocery and foodservice; 
- Limited selection convenience store: 1500-2200 sq. ft., similar to Mini C-store but with broader assortment of grocery and limited foodservice (e.g., hot dogs, nachos, etc.);

- Traditional convenience store: 2400-2500 sq. ft., product mix includes dairy, bakery, snack foods, beverages, tobacco, grocery, health and beauty aids, confectionary, prepared foods-to-go, fresh/frozen meats, gasoline, various services and produce items;

- Expanded convenience store: $2800-3600$ sq. feet; and have more shelving for grocery products or space for fast food service and seating;

- Hyper convenience store: 4000-5000 sq. ft., offer array of products and services arranged in departments, such as a bakery, a sit-down restaurant, or a pharmacy.

Convenience stores are also places where North Americans do as much as $40 \%$ of their food shopping, leading grocery stores to fight to reclaim the grocery territory (Preville, 2014), while dollar stores are expanding their offerings to infringe upon the traditional c-store territory. Convenience store expansion to maintain one's competitive advantage does not always assure success; service innovation has become the key strategy to stay in the lead (Wu, Huang, Tsai \& Chen, 2009). Innovation should meet your customers' needs.

\section{Literature Review}

\subsection{A Brief History}

Graves (2017) explores the evolution of convenience store operations in the context of consumers' ever-increasing sense of entitlement to time-efficient conveniences across a broad spectrum of daily practices. He posits that the rate at which conveniences become necessities appears to have increased over time, and the convenience store has evolved to serve this growing need. The combined effect of dual income families and longer working hours has led to a time-scarcity epidemic: a phenomenon that has been observed in North America, Europe, Asia and Australia (Hamermesh \& Lee, 2007). It should come as no surprise that a common theme that underlies many successful retail innovations is their ability to make the shopping experience more convenient (Reimers, 2013). Yet, despite an increasingly convenience-oriented society, very few empirical studies have identified convenience as a salient determinant of store patronage (Reimers, 2013). Virtually nothing has been written about c-stores outside of industry publications, crime journals, and public health research (Graves, 2017). According to this author, undermining their appeal as a subject for study is their lack of romantic appeal: They do not reflect American wanderlust, like motels, nor do they evoke nostalgia, like old gas stations. They are, to some, signifiers of cultural decay and urban degeneracy—staffed by immigrant employees, and constantly robbed at gunpoint.

However, convenience stores are part of our lifestyle and we give them little thought or consideration. The convenience store concept is nearly 100 years old. Jefferson Green, the operator of "Uncle Johnny's Ice Dock", is credited with inventing the convenience store formula in 1927 (NACS, 2005a). He began stocking staple food items like milk and bread to offset declining sales of ice in colder months, and extended operating hours to differentiate his store from the competitors. The latter served an emerging class of workers with nontraditional schedules. Recognizing the popularity of this concept, the parent company of Green's operation, Southland Ice Company, began copying his formula. With the repeal of prohibition, beer was added to the mix of products with great success. The company's chain of "Tote'm's" c-stores grew to sixty, and was copied by the competition. The chain later renamed its franchise "7-Eleven".

Widespread car ownership, expansion of suburbs, booming factory work, and the explosion of the tourism industry aided the growth and diffusion of c-stores during the 1950's (Graves, 2017). According to this author, the c-store design changed dramatically in the 1970's due to competition, car ownership, rising demands on time and the rising expectation of convenience, leading to novelties such as drive-through and curbside service, as well as self-serve gasoline retailing. He notes that the economic policies of the 1980's further accelerated the compression of time and space for many Americans who found the pressures on their time and disposable income increased, especially for working women who were often faced with a double "shift", thus expanding the industry faster than any other retail sectors. However, at this time, the oil industry started to offer convenience kiosks at their service stations to compete. Since the 1990's, co-branding, a business strategy that added fast food to the oil and groceries, grew in popularity, proved more profitable than most traditional stores due to shared site maintenance costs and property taxes (Graves, 2017). More recently, hyper-convenience stores, with several retail themes under one roof (e.g., c-store or mini-market, burger restaurant, ice cream shop, dry cleaner, etc.), were added to the typology of store design (NACS, 2005b) and represent the latest growth sector in this industry. 


\subsection{The Convenience Store Consumer}

It is often said that 80 percent of a convenience store's sales come from just 20 percent of its customers. "Core" customers were defined as those who make frequent visits to c-stores on a daily or weekly basis, and those who indicate they buy in-store items "every time" or "almost every time" after purchasing gas at a c-store (Hanson, 2016). According to this research, consumers aged 35-44 are significantly more likely to be daily or weekly c-store shoppers, and those aged 25-34 are significantly more likely to buy in-store merchandise after purchasing gas. Older customers, aged 55 and up, are significantly less likely to make daily or weekly c-store visits, or to stop in for a post-gas merchandise purchase. Whether their shopping trips are to get a take-home meal for the family or to indulge the kids with a special treat, parents have great potential to be core shoppers.

The 2018 Convenience Store Industry Report segments customers not along demographics but along their priorities and pain points. Customer segments include the Value Shopper, the Convenience Seeker, the Price Checker, and the Healthy Shopper. When choosing a convenience store, consumers' top three priorities are location, safety and gas prices. Alternately, Peterson (2010) identified four convenience store consumer segments according to their "need states", or their motivation for walking into and out of a c-store. They are: Mr. Jones - in the c-store because of life's simple addictions (tobacco, soda or snack); The Neighbor - the c-store is their community center, a ritualistic part of their day; The Last Minute Shopper-stops at the c-store on the way home on a mission for a very specific item; The Thrillseeker-want products that tap into their desire for emotion and will try anything once.

\subsection{Public Health Research}

In recent years, a stream of research has been published in the public health literature concerning the dietary impact of food selections offered by convenience stores. Since product offerings and location are an integral part of a company's marketing strategy, it is relevant to outline the social issues that may affect future strategic decisions of convenience stores. Convenience stores generally provide a greater assortment of less-healthy compared with healthier foods and beverages (Sharkey et al., 2012). Horner and Wood (2014) measure the accessibility people have to local food shopping opportunities given their activity patterns and available time budgets. They find that possible 'deserts' or areas of inaccessibility to grocery stores and supermarkets may force more reliance on convenience stores that carry less selection of healthy foods (Sharkey, Dean, Nalty \& Xu. 2013). Convenience stores in high-poverty communities were less likely to carry prepared salads than those in low-poverty communities (Zenk, Powel, Isgor, Rimkus, Baker \& Chaloupka, 2015). Greater availability of neighborhood convenience stores was associated with lower diet quality for participants with lower individual-level income, while associations at higher individual-income were weaker (Rummo et al., 2015).

In the case of adolescent obesity in the U.S., ease of access to convenience stores surrounding urban schools in the US is being associated with higher risk for obesity (Gebauer \& Laska, 2011). Nearly half of adolescents reported visiting convenience stores at least weekly. Significant risk factors for frequent visits were age, being African American, living in rural areas with higher levels of neighborhood deprivation (Sanders-Jackson, Parikh, Schleicher, Fortmann \& Henriksen, 2016). A regulatory mechanism is needed to reduce youth access to e-cigarettes and tobacco in convenience stores (Henriksen, Schleicher, Johnson \& Lee (2019). In a Canadian study of young adults aged 16-30, participants who reported better health made fewer purchases at convenience stores. The findings lend evidence to the idea that convenience stores, which commonly sell prepared and packaged foods, are not currently equipped to help shoppers maintain nutritious diets (Widener et al., 2018). Four studies, three in the U.S. and one in Canada, examined the impact of healthy corner store intervention (Beckelman et al., 2020; Caspi et al., 2017; Houghtaling et al., 2019; Minaker, Lynch, Cook \& Mah, 2017). They found that customers who shop at corner stores with more health promoting features (e.g., higher ration of shelf-space devoted to healthier products; greater variety of produce; produce visible from the store entrance) make healthier purchases, and creative strategies to increase sales of fresh vegetables and fruits seemed to substantially increase revenue from these product categories.

\subsection{Convenience Store Marketing Strategy Industry Trends}

Growth in healthy food and beverages sales led to positive overall sales at convenience stores in 2017, and retailers expect the momentum to continue according to a survey of retailers released by the National Association of Convenience Stores (NACS). The survey also predicted emerging trends for 2018: Kombucha drinks will continue to grow, as will new programs for home delivery (e.g., Uber), new payment methods (e.g., mobile payments, biometrics), healthier meal replacements, and the lunch daypart.

Loyal c-store shoppers respond more strongly to digital marketing: mobile app offers, promotions or messages on social media, and text messages are all significantly more likely to influence their decision to visit a c-store 
compared to other shoppers (Hanson, 2016). Positive word-of-mouth also influences c-store loyalty program success (Wishaw, Abulashesh \& Sumadi, 2019). Industry specialists recommend the use of point-of-sale software that includes a loyalty program for offering promos targeting frequent buyers; search engine optimization so that the c-store shows up in local search results; customers reviews of your business; use of TV inside your store to showcase promotions, and at the pump (Dizon, 2018).

Retail services such as drive-through and curb service will complement mobile ordering (Lewis, 2015). According to this author, in-store alcohol service and seating for hanging out and enjoying expanded food service are growing in popularity, as are vending machines for fast self-service (e.g., lottery tickets). She also states that seasonal merchandising, nostalgia for discontinued products, local specialties; smaller portions for tasting or side dishes are increasingly appealing to consumers.

Convenience store brand differentiation can be accomplished through four critical differentiating attributes that result in attracting twice as much customer spending than those that do not: differentiators (highly valued but perceived as rare, such as cleanliness); essentials (product/service offerings are expected); delighters (welcomed but not expected, such as fresh food); and low priorities (not highly valued, such as toys) (Lutz et al., 2014). Wu and Lin (2014) posit that the perception of ethical responsibility of a convenience store chain increases Generation X consumers' satisfaction levels and purchase intentions. This can be an influential differentiation factor in attracting these loyal consumers.

As noted earlier, although convenience stores play an important role in the retail industry and the lives of consumers, there is a scarcity of scholarly research on this form of distribution channel.

\section{Purpose of the Study}

The successful marketing strategy of convenience stores requires the identification of a target market and development of a marketing mix (product/service, place, price and promotion) that will best satisfy the needs of this target market. This research was first conducted in 2008 to investigate marketing strategies implemented by convenience stores and whether differences are found in Canada and the United States. The research was replicated ten years later to monitor marketing strategy developments in this industry.

\section{Methodology}

Following a methodology established in several studies (Heroux, 2002; Heroux \& Csipak, 2001, 2005; Heroux \& Burns, 2000), this exploratory study, using 24 case studies, was undertaken in 2008 and replicated in 2018 in the contiguous regions of southwestern Quebec and northern New York. There is substantial economic integration and cross-border traffic between the two countries in this region, and the hospitality industry targets business and leisure travelers of both nationalities (Church \& Heroux, 1999). For this reason, many similarities have been observed in these studies of the hospitality industry in these two countries.

A census of the convenience stores in two communities in this cross-border region was included in this research. The online Yellow Pages directory for the United States and Canada was used to identify the sampling frame of convenience stores in the contiguous geographic regions along the border. The region under study was expanded until 24 retail establishments were identified, representing the regions as follows: 12 from Quebec and 12 from New York. The typical convenience store in this study was an independently owned and operated family business that thus controlled its marketing strategy. The same convenience stores were revisited and data recorded 10 years later, following the same methodology described below. One interesting development in both regions is the conversion of the independent convenience store into a chain store, three establishments in Quebec, and two in New York.

Marketing strategy refers to the target market of the establishment and the marketing mix variables designed to attract these customers. The marketing mix variables are categorized according to the popular 4P framework (McCarthy \& Perreault, 2000): Product; Place; Price; and Promotion. A more detailed marketing strategy evaluation grid was developed from the commonly accepted variables in the marketing strategy literature (McCarthy \& Perreault, 2000; Kotler \& Armstrong, 2013; Jain, 2010; Pride \& Ferrell, 2014; Perreault et al., 2013, 2014; Lamb et al., 2012). Three of these categories of variables are subdivided in this study to capture the breadth of the categories: Product consists of product variety variables and service-related variables; Place refers to the location of the establishment as well as store atmospherics; and Promotion includes advertising variables and personal selling variables. This instrument was used to collect detailed qualitative observational descriptions and quantitative data of the convenience store marketing strategy variables. The comparison framework therefore consists of two cultural/geographic regions by eight marketing variable ratings. (See table 1). 
The observational research was conducted by international marketing students who were familiar with the marketing concepts. Observers received training on a variety of dimensions of the research process. They received a detailed explanation of each of the variables in the Marketing Strategy evaluation grid and how each variable is operationalized. They were shown how to find and approach their assigned convenience store, how to record their qualitative observations, and how to determine a quantitative score (on a scale of 1 to 5,5 being superior implementation) for each variable. For example, for breadth of product line, students would look at the assortment of products on the premises and make a judgment on the rating scale as to its appeal to consumers (5 would represent an outstanding assortment, beyond expectations; 3 would represent an average assortment usually found in convenience stores; and 1 would be the minimum one would expect). The trainer and trainees performed a "walk-through" of the research process prior to visiting the convenience store to ensure their understanding and consistent implementation of the data collection. Observation and listening were usually sufficient to gather information about each variable. For example, for the target market, they could look at license plates in the parking lot and see how many cars came from what state or province. They could tell what language, French or English, the customers spoke. They could ascertain if they were repeat customers if they appeared familiar with the establishment when they arrived, when they referred to past purchases, or when they were on first name basis with the staff. However, if some variables were difficult to observe, students were given guidelines for asking questions of the staff.

Table 1. Summary of the Marketing Strategy Variables Evaluation Grid (Heroux, 2002)

\section{Marketing Mix (4Ps)}

\section{Product:}

Product variety variables: Breadth of product line, assortment of accompanying products, size variations, quality, private labels/brands, special features, overall evaluation. (6 variables, maximum score of 30)

Service variables: customer services, customized/standardized, credit cards, empathy, reservations (computerization), hours of operation, guarantees, customer satisfaction (complaint handling), overall evaluation. (8 variables, maximum score of 40)

\section{Place:}

Location variables: Primary/secondary road (visibility), site evaluation (nearness to target market), outside appearance, private/public parking availability, detached building versus strip, general ease of access, overall evaluation. (6 variables, maximum score of 30)

Establishment atmospherics: Interior layout (free form, grid, racetrack); atmospherics—scent, lighting, color, mirrors, music, noise, signage; fixtures; cleanliness; size of crowds; type of clientele; access to disabled; overall evaluation. (12 variables, maximum score of 60)

\section{Price:}

Pricing variables: Relative high/low prices, competitive in region, group reductions, coupons/rebates, bundle or value pricing (packages offered), variety of payment options, overall evaluation. (6 variables, maximum score of 30)

\section{Promotion:}

Advertising variables: Newspapers, magazines, trade publications, television, radio, telemarketing, direct mail, internet, special promotions (sales, coupons, contests), outdoor ad and/or signage, advertising theme-testimonial, comparison, informative, humorous, etc., overall evaluation. (11 variables, maximum score of 55)

Personal selling variables: Approaching the customers, helpfulness, presenting product/service, making the sale, knowledgeable, art of listening, verbal/non-verbal cues, general appearance of staff, overall evaluation. (8 variables, maximum score of 40)

\section{Summary rating:}

Overall marketing strategy evaluation: addition of the overall rating in the eight categories.

Three trained observers visited each establishment together in both regions, spending 4-5 hours in each location to record detailed notes of how each marketing strategy variable was implemented. Then, the three observers had to discuss and come to an agreement on a score (on a scale of 1 to 5, 5 representing superior implementation of the strategy) for each variable in an attempt to quantify the observational data. Since this process resulted in one rating for each variable, inter-judge reliability measures were not relevant. Each item within a variable category 
was weighted equally in this research. The data collection thus consisted of qualitative data, the recorded observations, and quantitative data, the assigned scores for each variable. This methodology was effectively applied in other rural tourism marketing contexts (Heroux, 2002; Heroux \& Csipak, 2001, 2005; Heroux \& Burns, 2000).

\section{Results}

The findings are discussed below in terms of quantitative results and qualitative results. Tables 2 and 3 present the quantitative results of the scale ratings for each of the eight variable categories. Although tests of significance cannot be performed because of the small number of cases, inspection of the table reveals that there are more similarities than differences in marketing strategy variables in the two regions.

\subsection{Product Variety}

In 2008, convenience stores carried a wider assortment of products in the United States than in than in Canada. The majority of products in American establishments can be classified in terms of percentage of sales as fuel $(60-70 \%)$, cigarettes $(15 \%)$ groceries including candy soft drinks, snacks, and dairy products $(15 \%)$ and beer $(5 \%)$ with many stores offering meals and lottery tickets for sale. Ten years later, the assortment of products increased in both regions, the Canadian region surpassing the American region.

Depth of product line was higher in Canadian convenience stores in 2008, and reached a higher level in 2018. The American convenience stores have caught up over the last 10 years. Both regions continue to place a greater emphasis on fuel rather than the products offered in the store, although the store's supplement to the profits gained from customers is increasing. Canadians also continue to place greater emphasis on product quality than in the United States, resulting in lower inclination to purchase groceries at convenience stores. As such, convenience stores in Canada attract customers by having quality fuel and maintaining fuel price parity with the region. However, stores do sell a smaller variety of products such as coffee (68\% of location), wrapped sandwiches (61\% of locations), wrapped pastries (57\%) and fountain drinks (21\% of locations). In addition, an estimated $40 \%$ of sales can be attributed to the cigarette purchases. This high percentage of sales includes a higher level of taxation on this product category than in the United States. Branded products are similar in both regions but have decreased over the years, allowing for private labels and local products. Canadian convenience stores offered more special features in 2008 but this trend reversed over the past 10 years, with American convenience stores now offering more special features.

Table 2. Summary of Marketing Strategy Ratings

\begin{tabular}{|c|c|c|c|c|c|c|c|c|}
\hline \multirow[t]{2}{*}{$\begin{array}{l}\text { Marketing Strategy Variable } \\
\text { Ratings }\end{array}$} & \multicolumn{2}{|c|}{$\begin{array}{l}\text { New York } 2008 \\
N=12\end{array}$} & \multicolumn{2}{|c|}{$\begin{array}{l}\text { Quebec } 2008 \\
N=12\end{array}$} & \multicolumn{2}{|c|}{$\begin{array}{l}\text { New York } 2018 \\
N=12\end{array}$} & \multicolumn{2}{|c|}{$\begin{array}{l}\text { Quebec } 2018 \\
N=12\end{array}$} \\
\hline & Mean* & $\% * *$ & Mean* & $\% * *$ & Mean* & $\% * *$ & Mean* & $\% * *$ \\
\hline Product Variety & 19.2 & 63.9 & 20.5 & 68.3 & 22.2 & 74.0 & 22.0 & 73.3 \\
\hline Services & 22.4 & 56.0 & 22.4 & 56.0 & 22.8 & 57.0 & 23.3 & 58.3 \\
\hline Location & 20.3 & 67.8 & 22.3 & 74.2 & 26.4 & 88.0 & 26.0 & 86.7 \\
\hline Establishment Design & 34.9 & 58.2 & 37.8 & 59.6 & 40.4 & 67.3 & 41.1 & 68.5 \\
\hline Pricing & 12.5 & 41.7 & 12.3 & 41.1 & 18.2 & 60.7 & 18.8 & 62.7 \\
\hline Promotion & 11.8 & 21.5 & 12.6 & 22.9 & 13.0 & 23.6 & 13.8 & 25.1 \\
\hline Personal Selling & 21.2 & 52.9 & 22.1 & 50.2 & 26.7 & 66.8 & 29.1 & 72.8 \\
\hline Overall Strategy & 142.3 & 51.7 & 149.9 & 53.2 & 170.3 & 59.8 & 174.4 & 61.2 \\
\hline
\end{tabular}

*Mean: Average of the sum of ratings for all variables in the category.

**\%: The mean results are represented as a percentage of the maximum score that could be achieved for the variable category. 
Table 3. Quebec and New York Convenience Stores Marketing Strategy Variables Ratings

\begin{tabular}{|c|c|c|c|c|c|c|}
\hline & $\begin{array}{l}\text { New York } \\
2008 \\
\end{array}$ & $\begin{array}{l}\text { New York } \\
2018 \\
\end{array}$ & $\begin{array}{l}\text { Quebec } \\
2008 \\
\end{array}$ & $\begin{array}{l}\text { Quebec } \\
2018 \\
\end{array}$ & $\begin{array}{l}\text { Overall } \\
2008 \\
\end{array}$ & $\begin{array}{l}\text { Overall } \\
2018 \\
\end{array}$ \\
\hline Variable & $\begin{array}{l}\text { Mean } \\
\text { St Dev } \\
\end{array}$ & $\begin{array}{l}\text { Mean } \\
\text { St Dev } \\
\end{array}$ & $\begin{array}{l}\text { Mean } \\
\text { St Dev } \\
\end{array}$ & $\begin{array}{l}\text { Mean } \\
\text { St Dev } \\
\end{array}$ & $\begin{array}{l}\text { Mean } \\
\text { St Dev } \\
\end{array}$ & $\begin{array}{l}\text { Mean } \\
\text { St Dev } \\
\end{array}$ \\
\hline \multicolumn{7}{|l|}{ Product: } \\
\hline \multirow[t]{2}{*}{ Product line depth } & 3.33 & 4.20 & 3.75 & 4.30 & 3.51 & 4.25 \\
\hline & 1.07 & 0.79 & 0.75 & 1.06 & 0.88 & 0.91 \\
\hline \multirow[t]{2}{*}{ Assortment } & 3.50 & 4.00 & 3.08 & 4.20 & 3.21 & 4.10 \\
\hline & 1.00 & 1.15 & 0.99 & 0.79 & 1.01 & 1.07 \\
\hline \multirow[t]{2}{*}{ Sizes } & 3.08 & 3.70 & 3.33 & 3.60 & 3.22 & 3.65 \\
\hline & 1.16 & 1.16 & 0.98 & 0.97 & 0.91 & 1.04 \\
\hline \multirow[t]{2}{*}{ Quality } & 3.50 & 4.00 & 3.91 & 4.20 & 3.48 & 4.10 \\
\hline & 0.79 & 1.15 & 0.99 & 1.03 & 0.95 & 1.07 \\
\hline \multirow{2}{*}{ Brands } & 2.83 & 2.50 & 2.91 & 2.30 & 2.82 & 2.40 \\
\hline & 1.33 & 1.65 & 1.16 & 1.50 & 1.29 & 1.54 \\
\hline \multirow{2}{*}{ Special features } & 2.91 & 3.70 & 3.50 & 3.40 & 3.17 & 3.55 \\
\hline & 1.50 & 1.06 & 1.56 & 1.35 & 1.40 & 1.19 \\
\hline \multicolumn{7}{|l|}{ Service: } \\
\hline \multirow[t]{2}{*}{ Guest Services } & 3.66 & 3.40 & 3.25 & 4.40 & 3.37 & 3.90 \\
\hline & 1.30 & 1.51 & 1.48 & 1.07 & 1.30 & 1.37 \\
\hline \multirow[t]{2}{*}{ Customization } & 2.91 & 3.70 & 3.00 & 3.90 & 3.08 & 3.80 \\
\hline & 1.08 & 1.06 & 1.41 & 0.88 & 1.24 & 0.95 \\
\hline \multirow[t]{2}{*}{ Credit } & 3.50 & 3.90 & 3.41 & 4.00 & 3.08 & 3.95 \\
\hline & 1.73 & 1.59 & 1.67 & 1.33 & 1.72 & 1.43 \\
\hline \multirow[t]{2}{*}{ Empathy } & 2.91 & 4.30 & 2.83 & 4.60 & 2.94 & 4.45 \\
\hline & 1.16 & 0.67 & 1.26 & 0.69 & 1.21 & 0.69 \\
\hline \multirow[t]{2}{*}{ Hours } & 3.75 & 3.40 & 4.41 & 2.90 & 4.02 & 3.15 \\
\hline & 1.05 & 1.43 & 0.79 & 1.45 & 0.89 & 1.42 \\
\hline \multirow[t]{2}{*}{ Guarantees } & 1.83 & 4.20 & 2.33 & 4.20 & 2.00 & 4.20 \\
\hline & 1.26 & 0.92 & 1.30 & 1.14 & 1.21 & 1.00 \\
\hline Satisfaction & 2.83 & 4.00 & 3.16 & 3.90 & 3.00 & 3.95 \\
\hline & 1.52 & 1.49 & 1.52 & 1.66 & 1.49 & 1.54 \\
\hline Place-Location & & & & & & \\
\hline Visibility & 3.33 & 4.00 & 4.25 & 3.90 & 3.60 & 3.95 \\
\hline & 1.72 & 1.49 & 0.86 & 1.66 & 1.33 & 1.54 \\
\hline Site evaluation & 3.66 & 4.30 & 4.00 & 4.50 & 3.68 & 4.40 \\
\hline & 1.37 & 0.82 & 0.60 & 0.71 & 1.07 & 0.75 \\
\hline Appearance & 3.25 & 3.20 & 3.41 & 3.50 & 3.14 & 3.35 \\
\hline & 1.05 & 1.32 & 1.37 & 1.51 & 1.24 & 1.39 \\
\hline Parking & 3.25 & 4.00 & 3.33 & 3.50 & 3.17 & 3.75 \\
\hline & 1.21 & 1.05 & 1.30 & 1.51 & 1.22 & 1.29 \\
\hline Building type & 3.16 & 3.60 & 3.58 & 3.30 & 3.20 & 3.45 \\
\hline & 1.33 & 1.51 & 1.08 & 1.38 & 1.20 & 1.39 \\
\hline Accessibility & 3.66 & 4.50 & 3.66 & 4.20 & 3.60 & 4.35 \\
\hline & 1.30 & 0.85 & 1.23 & 1.14 & 1.28 & 0.99 \\
\hline Place-Atmosphere: & & & & & & \\
\hline Layout & 3.25 & 4.20 & 3.66 & 4.00 & 3.42 & 4.10 \\
\hline & 0.86 & 0.92 & 0.88 & 1.33 & 0.85 & 1.12 \\
\hline Scent & 2.83 & 4.10 & 3.25 & 4.20 & 3.05 & 4.15 \\
\hline & 1.19 & 1.37 & 1.13 & 1.32 & 1.18 & 1.31 \\
\hline Lighting & 3.75 & 3.70 & 3.66 & 4.10 & 3.48 & 3.90 \\
\hline & 1.35 & 1.25 & 1.55 & 1.10 & 1.35 & 1.17 \\
\hline Color & 2.91 & 3.80 & 3.33 & 3.60 & 2.91 & 3.70 \\
\hline & 1.24 & 1.03 & 1.30 & 1.65 & 1.31 & 1.34 \\
\hline Music & 1.50 & 2.00 & 2.50 & 2.90 & 2.02 & 2.45 \\
\hline & 0.90 & 1.07 & 1.44 & 1.27 & 1.27 & 1.17 \\
\hline Noise & 2.66 & 3.80 & 3.16 & 4.00 & 3.02 & 3.90 \\
\hline & 1.23 & 1.40 & 1.33 & 0.94 & 1.27 & 1.17 \\
\hline Signage & 3.50 & 3.60 & 3.00 & 3.30 & 2.90 & 3.45 \\
\hline & 1.31 & 0.97 & 1.59 & 1.57 & 1.50 & 1.28 \\
\hline Fixtures & 3.08 & 4.10 & 3.33 & 3.50 & 3.00 & 3.80 \\
\hline & 1.31 & 1.37 & 1.37 & 1.08 & 1.23 & 1.24 \\
\hline Cleanliness & 3.33 & 4.10 & 3.58 & 3.90 & 3.20 & 4.00 \\
\hline & 1.07 & 1.37 & 1.31 & 1.60 & 1.23 & 1.45 \\
\hline Crowdedness & 3.08 & 3.50 & 3.41 & 3.60 & 3.02 & 3.55 \\
\hline & 1.37 & 1.18 & 1.24 & 1.17 & 1.22 & 1.15 \\
\hline
\end{tabular}




\begin{tabular}{|c|c|c|c|c|c|c|}
\hline \multirow{2}{*}{ Registers } & 2.41 & 3.60 & 2.16 & 3.50 & 2.17 & 3.55 \\
\hline & 1.31 & 1.65 & 1.40 & 1.58 & 1.27 & 1.57 \\
\hline \multirow[t]{2}{*}{ Disable access } & 2.58 & 3.40 & 2.66 & 3.00 & 2.48 & 3.20 \\
\hline & 1.16 & 1.51 & 1.82 & 1.49 & 1.50 & 1.48 \\
\hline \multicolumn{7}{|l|}{ Price: } \\
\hline \multirow[t]{2}{*}{ Price level } & 3.33 & 3.50 & 3.33 & 3.60 & 3.31 & 3.55 \\
\hline & 0.77 & 1.51 & 0.49 & 1.17 & 0.71 & 1.32 \\
\hline \multirow[t]{2}{*}{ Competitive } & 3.00 & 3.10 & 3.00 & 3.60 & 2.91 & 3.35 \\
\hline & 1.04 & 0.99 & 1.20 & 1.17 & 1.14 & 1.09 \\
\hline \multirow[t]{2}{*}{ Group discount } & 1.66 & 1.30 & 1.58 & 1.50 & 1.60 & 1.40 \\
\hline & 1.07 & 0.67 & 0.90 & 1.08 & 0.97 & 0.89 \\
\hline \multirow[t]{2}{*}{ Coupons } & 2.16 & 1.90 & 2.16 & 2.30 & 2.00 & 2.10 \\
\hline & 1.46 & 1.29 & 1.19 & 1.77 & 1.18 & 1.52 \\
\hline \multirow{2}{*}{ Value bundling } & 2.33 & 3.20 & 2.25 & 3.40 & 2.22 & 3.30 \\
\hline & 1.43 & 1.81 & 1.35 & 1.51 & 1.33 & 1.63 \\
\hline \multicolumn{7}{|l|}{ Promotion-Ad: } \\
\hline \multirow[t]{2}{*}{ Print ads } & 1.50 & 1.80 & 2.08 & 1.70 & 1.82 & 1.75 \\
\hline & 1.00 & 1.14 & 1.24 & 1.47 & 1.09 & 1.29 \\
\hline \multirow[t]{2}{*}{ Broadcast ads } & 1.58 & 1.80 & 1.50 & 1.80 & 1.45 & 1.80 \\
\hline & 0.99 & 1.39 & 1.00 & 1.48 & 0.88 & 1.39 \\
\hline \multirow[t]{2}{*}{ Other ads/web } & 1.25 & 2.30 & 1.41 & 2.60 & 1.34 & 2.45 \\
\hline & 0.62 & 1.42 & 0.79 & 2.06 & 0.68 & 1.73 \\
\hline \multirow[t]{2}{*}{ Special promos } & 2.58 & 2.30 & 2.33 & 2.60 & 2.31 & 2.45 \\
\hline & 1.56 & 1.34 & 1.07 & 1.84 & 1.23 & 1.57 \\
\hline \multirow[t]{2}{*}{ Outdoor sign } & 3.33 & 1.40 & 2.91 & 1.80 & 2.88 & 1.60 \\
\hline & 1.37 & 0.84 & 0.99 & 0.92 & 1.18 & 0.88 \\
\hline \multirow[t]{2}{*}{ Ad theme } & 1.58 & 2.70 & 2.33 & 2.80 & 1.82 & 2.75 \\
\hline & 1.08 & 1.83 & 1.23 & 1.75 & 1.12 & 1.74 \\
\hline \multicolumn{7}{|l|}{ Promotion-Selling: } \\
\hline \multirow[t]{2}{*}{ Approach } & 2.58 & 3.10 & 2.41 & 3.30 & 2.48 & 3.20 \\
\hline & 1.31 & 1.45 & 0.99 & 1.64 & 1.17 & 1.51 \\
\hline \multirow[t]{2}{*}{ Helpfulness } & 2.91 & 3.30 & 2.83 & 3.90 & 3.00 & 3.60 \\
\hline & 1.44 & 1.57 & 1.58 & 1.66 & 1.41 & 1.60 \\
\hline \multirow[t]{2}{*}{ Food presentation } & 2.16 & 3.00 & 2.91 & 3.20 & 2.22 & 3.10 \\
\hline & 1.26 & 1.15 & 1.67 & 1.32 & 1.39 & 1.21 \\
\hline \multirow[t]{2}{*}{ Making a sale } & 2.16 & 3.20 & 2.41 & 2.90 & 2.31 & 3.05 \\
\hline & 1.40 & 1.32 & 1.50 & 1.37 & 1.34 & 1.32 \\
\hline \multirow[t]{2}{*}{ Knowledge } & 2.75 & 3.70 & 2.75 & 3.70 & 2.80 & 3.70 \\
\hline & 1.48 & 1.25 & 1.42 & 1.64 & 1.40 & 1.42 \\
\hline \multirow[t]{2}{*}{ Listening } & 3.08 & 3.60 & 2.91 & 4.00 & 3.22 & 3.80 \\
\hline & 1.37 & 1.50 & 1.37 & 1.15 & 1.26 & 1.32 \\
\hline \multirow[t]{2}{*}{ Nonverbal cues } & 2.66 & 3.00 & 2.58 & 3.50 & 2.82 & 3.25 \\
\hline & 1.55 & 1.56 & 1.37 & 1.27 & 1.42 & 1.41 \\
\hline Appearance & 2.83 & 3.80 & 3.25 & 4.20 & 3.14 & 4.00 \\
\hline & 0.71 & 1.48 & 1.05 & 1.23 & 0.91 & 1.34 \\
\hline
\end{tabular}

\subsection{Services}

Services are standardized for convenience stores for both regions. As a result, many convenience stores are open 24 hours a day, 7 days a week with limited service offering such as ATM usage, newspaper stands, credit card and debit card payment options and lottery ticket distribution. Guest services have improved in both regions over the past 10 years, as have the express guarantees stated by the stores. Employee training has increased the level of empathy of store employees and the resulting handling of customers complaints to achieve customer satisfaction.

\subsection{Location}

Given the nature of the type of retail establishment, (convenience stores selling products for the convenience of consumers), the majority of companies are located in convenient high traffic areas. This is especially true of stores located off major interstate highways whose aim is to attract truckers and other travelers. In densely populated neighborhoods, stores are likely to be located near high traffic intersections since their long-term viability depends on customers within a two to six mile shopping radius. Convenience stores in all regions appear to be equally accessible. The Quebec location still has superior ratings on store appearance but parking facilities are now better at the American convenience stores. 


\subsection{Establishment Design}

Most of the convenience stores in the two regions followed a grid design similar to what would be found in a supermarket. Quebec stores generally had better layouts, scent, color, music, fixtures, and the space felt less crowded. They also had better access for the disabled, and were the cleanest establishments, which is important in a food environment. The American establishments had better signage and lighting to make the products stand out. Ten years later, all variables had improved in both regions. American store layouts, color scheme, fixtures, cleanliness and disabled access had improved and surpassed the Canadian establishments. Scent, lighting, music, noise, and crowdedness continue to be superior in Canadian convenience stores (Table 4).

Table 4. Convenience Store Atmospherics

\begin{tabular}{lll}
\hline Atmospherics & American & Quebec \\
\hline Scent & Brewed Coffee/Products for Sale & Coffee or None \\
Lighting & Very bright & Bright \\
Music & From local radio & French radio \\
Signage & Visible outside/promotions Inside & Visible signs on refrigerators, for lotto \\
Noise & From traffic, people talking & None \\
\hline
\end{tabular}

\subsection{Price}

Although convenience stores offer customers the opportunity to access groceries and other necessities more readily, this convenience comes at a higher cost to the customers. The findings indicate that pricing of goods was medium to high as compared to similar prices at supermarkets and other shopping centers. This was consistent in both regions. In addition, there were limited opportunities for customers to get group rates, value bundles or coupons due to distributor policies. However, because gas sales are the driving force for store traffic, companies tend to price gas competitively. Ten years later, Canadian prices were slightly more competitive as did coupon usage. Value bundling had increased in both regions (e.g., 2 for $\$ 3$, meal combos, etc.).

\subsection{Promotion}

Because price and location are the primary driving forces for convenience stores, there is a general lack of promotion in both regions from 2008 to 2018 . Companies do not try to attract customers through direct mail, Internet, telemarketing, radio, television or trade publications. Rather, customers are able to gain awareness of these convenience stores through the usage of the Yellow Pages directories, outdoor signage and special promotions. These include reduced gas prices, participation in loyalty program, or limited time offers on products in the store. Overall, there is more promotion done by Canadian than by the American convenience stores. The only change in the past 10 years has been the increased use of web advertising, but this is still at a low level.

\subsection{Personal Selling}

In 2008, customers were more likely to receive a greeting from an employee when entering the American convenience stores than when entering a Canadian convenience store. However, Quebec convenience stores had a higher rating for employees attempting to make a sale, while employees in American convenience stores were well versed in the art of listening and their broad knowledge about the products available. Ten years later, Canadian store employees gave more greetings, were more helpful, were better listeners and better versed in non-verbal cues, and had a more professional appearance. Employee knowledge had increased similarly in both regions, but the American employees were more likely to make the sale. In both regions, employee training appears to have improved significantly in the past 10 years with a successful outcome.

\section{Discussion}

As seen by the data presented above, convenience stores have gradually continued to adapt their marketing mix to their target market. As a result, convenience stores in both regions have been able to offer products and services that will bring about repeat sales and increase their profitability, for the convenience that is worth the higher prices to consumers. Convenience stores offer customers time saving while offering what they value most: fast service, expedient locations, quality customer service and an adapted marketing mix.

Although there were more similarities than differences in marketing strategies in both regions, Quebec convenience stores were the most effective in implementing their marketing mix and adapting their strategy. Convenience store marketing strategies have improved in both regions in the past 10 years. Product assortment and depth of product lines have improved, as have the size options and quality of products. Although generally 
standard, services have improved with respect to payment options, guarantees, complaint handling and employee empathy toward customers. Availability of parking and accessibility from the road have also improved. Although the outside of the building have not changed over time, the interior atmosphere has been upgraded through renovations. In both regions, the interior layout, scent management, color scheme, signage, fixtures, cleanliness crowdedness and access to the disabled have improved. Price levels have become more competitive and value bundling more popular. Promotion is still the weakest marketing strategy variable, with some increase in web advertising in both regions. On the other hand, the personal selling effort has improved through training, with employees approaching the customers, being more knowledgeable, listening to customers, making the sale, having a more professional appearance. However, in both regions, there is room for improvement.

In both regions, there are opportunities for convenience stores to offer special features that draw repeat customers, such as a loyalty program or special beverage or fresh food products. Hours of operation can be expanded, store outside appearance improved. There is also room for improvement for indoor signage, and access for the disabled. Price discounts through loyalty programs may be considered. Promotion through social media and mobile marketing applications, and training employees to make the sale or upsell may also be considered. In addition, Canadian convenience stores can improve parking and stores fixtures while American convenience stores can improve lighting, music, employee helpfulness to customers, and their professional appearance.

\section{Conclusion}

This research has highlighted the changes that have evolved in convenience store marketing strategies over a decade, and identified areas of strength and weaknesses to guide practitioners to improve their strategies for the future. The above findings are limited in sample size and in scope, and generalization beyond the regions under observation should be undertaken with caution. More research is needed in other Canadian provinces and American states.

\section{References}

Beckelman, T., Sinclair-White, B. M., McGurk, M. D., Donohoe-Mather, C., Vu, U., Ching, L. K., ... Keliikoa, L. B. (2020). Encouraging adults to choose healthy now: A Hawai 'i convenience store intervention. Journal of Nutrition Education and Behavior, 52(3), 330-334. https://doi.org/10.1016/j.jneb.2019.11.016

Canadian Convenience Store Association (2017). www.ccsa.org.

Caspi, C. E., Lenk, K., Pelletier, J. E., Barnes, T. L., Harnack, L., Erickson, D. J., \& Laska, M. N. (2017). Association between store food environment and customer purchases in small grocery stores, gas-marts, pharmacies and dollar stores. International Journal of Behavioral Nutrition and Physical Activity, 14(76). https://doi.org/10.1186/s12966-017-0531-x

Church, N. J., \& Heroux, L. (1999). Canadian and American travellers: fraternal twins? An exploratory study of hotel macro-choice criteria, In Ralston, C. (ed.) Proceedings of the Administrative Sciences Association of Canada Conference, Saint John, New Brunswick, 20(23), 22-30.

Convenience Store Industry Report (2018). Trendsource, April 4.

Dizon, A. (2018, July 27). Top 27 convenience store marketing tips from the pros. FitSmallBusiness.com

Gebauer, H., \& Laska, M. N. (2011). Convenience stores surrounding urban schools: An assessment of healthy food availability, advertising, and product placement. Journal of Urban Health: Bulletin of the New York Academy of Medicine, 88(4), 616-622. https://doi.org/10.1007/s11524-011-9576-3

Graves, S. M. (2017). Convenience stores: A landscape perspective. Yearbook of the Association of Pacific Coast Geographers, 79, 134-152. https://doi.org/10.1353/pcg.2017.0007

Hanson, A. (2016). Who is today's core convenience store shopper? Convenience Store News, April 13.

Henriksen, L., Schleicher, N. C., Johnson, T. O., \& Lee, J. G. (2019). Assurances of voluntary compliance: A regulatory mechanism to reduce youth access to E-cigarettes and limit retail tobacco marketing. American Journal of Public Health, (0), e1-e7.

Heroux, L. (2002). Restaurant marketing strategies in the United States and Canada: A comparative study. Journal of Foodservice Business Research, 5(4), 95-110. https://doi.org/10.1300/J369v05n04_07

Heroux, L., \& Burns, L. (2000). Comparative marketing strategies of bed-and-breakfasts in Canada and the United States: An exploratory study. In Church, N. J. (Ed.), Proceedings of the Administrative Sciences Association of Canada Conference, Montreal, Canada, 21(23), 21-28. 
Heroux, L., \& Csipak, J. (2001). Comparative marketing strategies of motels in Canada and the United States: An exploratory study. In Heroux, L. (Ed.), Proceedings of the Administrative Sciences Association of Canada Conference, London, Ontario, 22(23), 35-44.

Heroux, L., \& Csipak, J. (2005). Marketing strategies of bars in the United States and Canada: A comparative exploratory study. Journal of Foodservice Business Research, 8(2), 55-72 https://doi.org/10.1300/J369v08n02_05

Horner, M. W., \& Wood, B. S. (2014). Capturing individuals' food environments using flexible space-time accessibility measures. Applied Geography, 51, 99-107. https://doi.org/10.1016/j.apgeog.2014.03.007

Houghtaling, B., Serrano, E. L., Kraak, V. I., Harden, S. M., Davis, G. C., \& Misyak, S. A. (2019). A systematic review of factors that influence food store owner and manager decision making and ability or willingness to use choice architecture and marketing mix strategies to encourage healthy consumer purchases in the United States, 2005-2017. International Journal of Behavioral Nutrition and Physical Activity, 16(1), 5. https://doi.org/10.1186/s12966-019-0767-8

Jain, A. (2010). Principles of marketing. VK Publications.

Kotler, P., \& Armstrong, G. (2013). Principles of marketing (15th ed.). Pearson Education.

Lamb, C. W., Hair, J. F., \& McDaniel, C. (2012). Marketing (12nd ed.). Cengage Learning.

Lewis, A. (2015, November). 20 for '16: The biggest trends and greatest ideas for the coming year. CSP Daily News. Retrieved October 2, 2017, from https://www.cspdailynews.com/print/csp-magazine/article/20-16?page $=0 \% 2 \mathrm{C} 1$

Lutz, T., Bolden, D., Portera, T., \& Gade, M. (2014, February 18). The evolving convenience-store consumer. Retrieved from https://www.bcg.com/publications/2014/retail-marketing-sales-evolving-convenience-store-consumer.aspx

McCarthy, J. E., \& Perreault, W. D. (2000). Essentials of marketing (8th ed.). Irwin.

Minaker, L. M., Lynch, M., Cook, B. E., \& Mah, C. L. (2017). Exploring sales data during a healthy corner store intervention in Toronto: the food retail environments shaping health (FRESH) project. Health Promotion and Chronic Disease Prevention in Canada: Research Policy and Practice, 37(10), 342-349. https://doi.org/10.24095/hpcdp.37.10.04

National Association of Convenience Stores (2005a). A short history of the convenience store. Retrieved from http://www.nacsonline.com/NACS/Resource/IndustryResearch/cstore_history.htm

National Association of Convenience Stores. (2005b). What is a convenience store. Retrieved from http://www.nacsonline.com/NACS/Resource/IndustryResearch/what_is_a_cstore.htm

National Association of Convenience Stores. (2018). From food to fuel and healthy choices, retailers see good things ahead for the New Year, as well as areas to keep an eye on. January 02.

Perreault, J. W., Cannon, J., \& McCarthy, J. (2014). Essentials of marketing: A marketing strategy planning approach (14th ed.). McGraw-Hill Irwin.

Perreault, Jr. W., Cannon, J., \& McCarthy, J. (2013). Basic marketing: A marketing strategy planning approach (19th ed.). McGraw-Hill Irwin.

Peterson, B. (2010, June 6). The four types of convenience store shoppers. Retrieved October 2, 2017, from https://www.retailcustomeresperience.com/articles/the-four-types-of-convenience-store-shoppers/

Preville, P. (2014). The store that never sleeps. Canadian Business, 87(5/6), summer, 44-46.

Pride, W. M., \& Farrell, O. C. (2014). Foundations of marketing, 6th Ed, Cengage Learning.

Reimers, V. (2013). A consumer definition of store convenience (finally). International Journal of Retail \& Distribution Management, 42(4), 315-333. https://doi.org/10.1108/IJRDM-03-2013-0060

Rummo, P. E., Meyer, K. A., Boone-Heinoren, J., Jacobes, D. R., Kiefe, C. I., Lewis, C. E., Steffen, L. M., \& Gordon-Larsen, P. (2015). Neighborhood availability of convenience stores and diet quality: Findings from 20 years of follow-up in the coronary artery risk development in young adults study. American Journal of Public Health, 105(5), e65-e73. https://doi.org/10.2105/AJPH.2014.302435

Sanders-Jackson, A., Parikh, N. M., Schleicher, N. C., Fortmann, S. P., \& Henriksen, L. (2015). Convenience store visits by US adolescents: Rationale for healthier retail environments. Health Place, 34, 63-66. 
https://doi.org/1000.1016/j.healthplace.2015.03.011

Sharkey, J. R., Dean, W. R., \& Nalty, C. (2012). Convenience stores and the marketing of foods and beverages through product assortment. American Journal of Preventive Medicine, 43(3S2), S109-S115. https://doi.org/10.1016/j.amepre.2012.05.012

Sharkey, J. R., Dean, W. R., Nalty, C., \& Xu, J. (2013). Convenience stores are the key food environment influence on nutrients available from household food supplies in Texas border Colonias. BioMedical Central Public Health, 13(45). https://www.biomedicalcentral.com/1471-2458/13/45

The State Journal (2011, October 21). Selling convenience. Charleston, 27(41), S14.

Widener, M. J., Minaker, L. M., Reid, J. L., Patterson, Z., Ahmadi, T. K., \& Hammond, D. (2018). Activity space-based measures of the food environment and their relationships to food purchasing behaviours for young urban adults in Canada. Public Health Nutrition, 21(11), 2103-2116. https://doi.org/10.1017/s1368980018000435

Wishah, R., Abuhashesh, M., \& Sumadi, M. A. (2019). The role of positive word of mouth on the success of convenience store loyalty programs. Int. J. Islamic Marketing and Branding, 4(2), 95-103. https://doi.org/10.1504/IJIMB.2019.104532

Wu, S. H., Huang, S. C. T., Tsai, C. Y. D., \& Chen, Y. C. (2009). Service innovation in franchising convenience store: An exploratory study. International Journal of Electronic Business Management, 7(2), 137-148.

Wu, S. I., \& Lin, H. F. (2014). A correlation of CSR and consumer behavior: A study of convenience store. International Journal of Marketing Studies, 6(6), 66-80. https://doi.org/10.5539/ijms.v6n6p66

Zenk, S. N., Powell, L. M., Isgor, Z., Rimkus, L., Barker, D. C., \& Chaloupka, F .J. (2015). Prepared food availability in U.S. food stores, American Journal of Preventive Medicine, 49(4), 553-562. https://doi.org/10.1016/j.amepre.2015.02.025

\section{Copyrights}

Copyright for this article is retained by the author(s), with first publication rights granted to the journal.

This is an open-access article distributed under the terms and conditions of the Creative Commons Attribution license (http://creativecommons.org/licenses/by/4.0/). 